\title{
Judicial ACtivism In Nigeria: Delineating The EXTEND Of Legislative-JUdicial ENgAgEMENT IN LAW MAKING
}

\author{
Ibrahim Imam ${ }^{1}$
}

\section{Faculty of Law University of Ilorin, Ilorin, Nigeria email: omotosho200620@yahoo.com}

IMAM, Ibrahim. Judicial Activism In Nigeria: Delineating The Extend Of Legislative-judicial Engagement In Law Making. International and Comparative Law Review, 2015, vol. 15, no. 1, pp. 109-127. DOI: 10.1515/iclr-2016-0030.

\begin{abstract}
Authoritarian governments are by their very nature unconstitutional. Such government thinks of themselves as above the law, and therefore sees no necessity for separation of powers or representative governance. Constitutional democracy on the other hand, is however based on the notion of people's sovereignty, which is to be exercised in limited manner by a representative government. Accordingly, judicial activism in this paper is employed to establish the theory of popular participation of courts in the decision making processes through settlement of disputes, interpretation or construction of laws, determination of propriety of legislations, legislative and execution actions within the doctrine of separation of powers for the purpose of enforcement of the limitations in government on constitutional ground. This paper thus examines the concept of judicial activism, its legitimacy and as a mechanism for providing checks and balances in the Nigerian government. The paper demonstrates a game theory of judicial legislative interaction within their function and contends that the notion of judicial supremacy does not hold water because the legislature always has the second chance of invalidating the judgment of courts exercising the legitimate powers. The paper concludes that judicial activism in these countries is a veritable tool in advancing the compliance with the rule of laws on the ground of the Constitution.
\end{abstract}

Keywords: Judiciary, Interpretation, Activism, Legislature, Constitution, Democracy, Intervention Adjudication, Separation, power.

\section{Introduction}

The power of government and its limitations by the Constitution has been a difficult question in any democracy around the world. The inception of the

1 LL.B (Usumanu Danfodiyo University, Sokoto, Nigeria), BL. (Nigerian Law School, Abuja, Nigeria), LL.M (Obafemi Awolowo University, Ile-Ife, Nigeria) and Ph.D. (University of Ilorin, Ilorin, Nigeria); Lecturer, Faculty of Law, Department of Public Law, University of Ilorin, Ilorin, Nigeria, e-mail: omotosho200620@yahoo.com.

\section{(c) Palacký University Olomouc, Czech Republic, 2015. ISSN 1213-8770 (print), ISSN: 2464-6601 (online).}


Nigerian nascent democracy in 1999 has witnessed a rising public expectations in the realm of protection and enforcement of the rights of citizen which seemed to have been eroded during country's experience of Military rule and guarantee minimum levels of security. The immense powers exercised by governments over their own citizens have arisen almost entirely from the collective aspirations of the citizen at large, aspirations which depend for their fulfillment on government intervention in many areas of our national life, and which no democratic political actors can ignore. ${ }^{2}$ The facts however remains that a powerful executive is inherent characteristic of the Nigerian modern democracy. The proper role of the judiciary in constraining the action of the legislature and the executive thus became imperative. ${ }^{3}$

Nigeria as a society divided along the line of ethnicity, regionalism, and religious dichotomy most often do experience lot of controversies, and appeal of litigation has been particularly strong with citizens' increasingly viewing judicial intervention as principal opportunity to shape the public sphere. The Nigerian Constitution 1960, 1963, 1979 and 1999 (as amended in 2010) placed the judiciary in this tasking position with a number of provisions that deal with structure, functions and powers of the judiciary. ${ }^{4}$ It introduced a unified system in all the states. The Constitution introduced judicial system in hierarchy viz. The Supreme Court of Nigeria, the apex court of the land, the Court of Appeal and the High courts, Shariah Courts' of Appeal and Federal High Court. Although the Constitution contains specific provisions relating only to the Supreme Court, Court of Appeal and Federal High Courts it leaves the subordinate judiciary to the states.

Thus, the judiciary plays a vital role as social activist in the Nigerian progressive democratic reality. This growing role and level of judicial intervention depend on the Nigerian legal system where it operates a written Constitution, thus judiciary still exercise only a limited power just as the other institutions of the executive and the legislature. The role of the Nigerian judiciary is basically in the realm of disputes settlement and interpretation of Constitution or Statutes. ${ }^{5}$ However, in Nigeria like many countries operating written Constitution, judici-

2 The most recent incident of deploying heavy security (a combined force of Military and Police) to supervise Ekiti and Osun States governorship election under guise of preventing violence and ensuring a free and fair election typified example of executive disrespect of peoples' rights in Nigeria.

3 Meernik, J. \& Joseph I., Judicial Review and Coordinate Construction of the Constitution, 41, American J. of Political Science, 447, (1997)

4 The primary judicial function vested by the Constitution in Courts is to decide disputed questions of fact and law in accordance with the law laid down and expounded by the Courts. Judicial power is the authority exercised $b$ the judicial department of the constitution charged with the declaration of what the law is and its construction. The exercise of judicial function also involves the investigation of facts. See A G. (Federation) v Guardian Newspaper (1999) 5 SC (pt iii) 59 at 107

5 Id 
ary has been under attack for assuming a posture of imperialism or supremacy in the scheme of governance. This proposition may not be true in that the powers are ultimately as limited as is that of the executive and the legislature in their several assignments. ${ }^{6}$ However the provision of the Constitution enables the institutions to provide checks and balances on each other if any indulge in excessive, arbitrary or tyrannical use of the power.

Against the above backdrop and by virtue of section 6(6) of the Nigerian Constitution the judiciary has come to exercise vast powers of judicial review from which judicial activism metamorphous in respect of the legislative and executive functions. The judiciary as represented by Courts not only act as the third independent arbiters to determine disputes that may arise between the federal and states but also protect and enforce the fundamental rights of the citizens against the arbitrary action of the states. They also interpret the laws made by the legislature and they have the final say in the validity of any legislative or executive action of the state if it contravenes or abridges the fundamental rights of citizens. Thus the Nigerian judiciary as represented by courts generally performs one or all of the following functions in constitutional democracies:

1. Interpretation of the Constitution or law;

2. Upholding the principle of Federalism by enforcing the balance between the Federal and States organs of Government; ${ }^{8}$

3. Protection of fundamental rights of the citizens; ${ }^{9}$

4. Determining the validity of legislative, quasi-legislative, executive or quasi-judicial actions on issues that touch the Constitution; ${ }^{10}$ and

5. Determining the consistency or inconstancy of a legislation to the Constitution by applying and interpreting the laws of the legislature. ${ }^{11}$

These functions give the courts ability to provide citizen with limited access to the majority-led legislature and executive an enabling environment to challenge unpopular and oppressive policies through the litigation. ${ }^{12}$ Admittedly courts have come to exist for the protection of and enforcement of citizens' rights who put their views across with all potency for them to vent their feelings. This paper argued for the concept of judicial activism with the object of demonstrating that the judiciary as represented by Courts employs the concept within its

6 Ibrahim I., the Executive, Legislative and Judiciary: An Insight into their functions under the Nigerian Democratic Setting, 4:1, Journal for the Promotion of Studies in Religion, Education and Languages (JOPSREL) 8-9, (2005)

7 The spirit behind section 6(6) of the Nigeria Constitution 1999 as amended

8 The Federal, state and Local Governments in Nigeria are autonomous by virtue of sections 4, 5 and 6 ibid

9 See section 46 ibid

10 See sections $1(3)$ and $4(8)$ ibid

11 Section 1(3) ibid

12 Like the case of Attorney General of Abia State \& 35 ors v Attorney General of the Federation (2006) 9 MSSC 1 
constitutional powers and limitations to ensure compliance with rule of law and see that justice is always achieved. This paper will argued in favour of judicial activism and the necessary implication of activist court establishing the rule of law, protection of citizen rights, limiting excess in governance and determining the validity of legislation, legislative and executive actions through checks and balances scheme of the Constitution and purposeful interpretation of laws. The paper is limited to the exploration of judicial role within the concept of separation of powers with particular reference to the Supreme Court being the final court of appeal in the hierarchy of courts and whose decision binds all other lower courts. ${ }^{13}$

\section{Historical Development of Judicial Activism in Nigeria}

Instructively the concept of judicial activism has its origin from the English common law imported into the country ${ }^{14}$ Nigeria and more particularly influenced by the United States of American judicial practice which is attached to the very original debate about constitutional interpretation framed in terms of broad versus strict construction or narrowly and or broadly. ${ }^{15}$ Significantly the origin of judicial activism is linked to the power of judicial review asserted by the Supreme Court in Marburry v Madison in $1803 .{ }^{16}$ Incidentally, there is no provision in the United States Constitution where the power of judicial review is contained. ${ }^{17}$ Yet in the United States, scholars have criticised and accused the Supreme Court, its judgments and judges of judicial activism and, to support their submissions, the cases most often cited are Lawrence v Texas, ${ }^{18}$ United States v Morrison, ${ }^{19}$ Brown

13 Agbede I. A., The Rule of Law and Preservation of Individual Rights, Ajomo and Bolaji (eds.) Individual Rights under the 1989 Constitution, (NIALS, 1993) p. 40

14 Nweze C. C., Statutory Interpretation; the Impregnable Reign of Literalism, Nigerian JR p. 145 (1978-1988)

15 See Freeman Barry, The History of Conter-majoritarian Difficulty, Law's Politics, 148, University of Pennsylvania Law Review, (2000)

16 Spaeth, Harold, The Judicial Restraint of Mr. Justice Frankfurter-Myth or Reality, 8:1 Midwest J. of Political Science, 22, (1964)

17 Ernest A. Y., Judicial Activism and Conservative Politics, University of Colorado Law Review, (2002)

18539 US 558 (2003), was a Landmark decision of United States' Supreme Court which struck out the Sodomy Law in Texas and by proxy invalidated sodomy law in thirteen other states where they remained in existence, thereby making same-sex sexual activity legal in every states and territories of the nation. (The case was based on Texas Law, classifying consensual adult homosexual intercourse illegal. The US Supreme Court had previously addressed the issue in 1986 in the case of Bowers v Hardwick 478 US 186 (1986) 149 where it upheld the challenged Georgia statute not finding a constitutional protection for sexual privacy. Lawrence's case explicitly overruled Bower's holding that it had viewed the liberty interest too narrowly.

19529 US 598 (2000) was another landmark United States Supreme Court's decision which held part of the Violent Against Women of Act 1994 unconstitutional because they exceeded congressional power under the Commerce Clause and under Section 5 of the $14^{\text {th }}$ Amendment to the Constitution. In 1994, the United States Congress passed Violent 
$\mathrm{v}$ Board of Education of Topeka ${ }^{20}$, Roe v Wade ${ }^{21}$ and United States v Lopex ${ }^{22}$ to mention but a few have often been used as points of reference. ${ }^{23}$

In order to give a graphic exposition of judicial activism in Nigeria and the game theory of synergy between the executive and legislature in the form of providing checks and balances, it is important to start with a prefatory historical linkage of the concept with the Nigerian judiciary particularly the Supreme Court. It is not certain and difficult to trace the origin of judicial activism linkage with the Nigeria judiciary. The judiciary has come to be established as an independent organ of the government in the Nigerian constitutional democracy since enactment of the 1963 Constitution and subsequently under the 1979 and 1999 Constitutions of Nigeria. It is worthy to note that the period after the declaration of the Federal Republic of Nigeria a few instances evidenced that the Supreme Court exhibited certain elements of judicial activism which established the Court linkage to judicial activism. Adegbenro v Akintola, ${ }^{24}$ Williams v Majekodunmi, ${ }^{25}$ Council of University of Ibadan v Adamolekun ${ }^{26}$ and Lakanmi v Attorney General Western Nigeria ${ }^{27}$ and other decisions vindicating the rights of Nigerians. ${ }^{28}$

The judiciary has since claims the power to nullify on constitutional grounds inclusive of inconsistent acts of the legislature to the Constitution, or check excesses of the executives. Though courts do not doubt the privileges of the legislature or the executive especially in respect of their internal proceedings, yet such proceedings have been brought under the purview of judicial review. ${ }^{29}$ Thus the examples of judicial courage and creativity exhibited by the Supreme Court

Against Women Act which contained a provision for a federal civil remedy to a victim of gender-based violence even when no criminal charges were filed.

20347 US 483 (1954) the United State Supreme Court declared State Laws establishing separate public school for black and white students unconstitutional. The case overturned the Plessy v Ferguson 163 US 537 (1896) decision of 1896 which allowed separate but equal segregation facilities on public transportation were constitutional.

21410 US 113 (1973) the United State Supreme Court decision under the Due Process Clause of the $14^{\text {th }}$ Amendment where the court resolved the balancing test by tying state regulation of abortion to the women's current trimester of pregnancy. See also Doe v Boltton 410 US 199 (1993)

22514 US 549 (1995)

23 See generally Kermit, R., The Myth of Judicial Activism: Making Sense of the United States' Supreme Court Decisions, (2008) Yale University Journal, (2008), Keenan D. K, The Origin and Current Meaning of Judicial Activism, 93, California L.R., 1444-1442, (2004)

24 (1963) All NLR 305 Akintola v Adegbenro (1962) 1 All NLR 442

25 (1963) 2 SCNLR 26

26 (1967) NSCC 210

27 (1970) NSCC 143

28 Shugaba Darma v Minister of Internal affair, (his deportation from Nigeria was declared unconstitutional and an infringement of his fundamental right, Fawehinmi v Akilu \& Togun (1987) 4 NWLR (pt 67) p 779 a landmark judgment to validates a private person's right to prosecution of crime.

29 Inakoju v Adeleke (2007) 2 MJSC 1, Dapianlong v Dariye (2007) 8 MJSC 140, Ugwu v Ararume (2007) 7 MJSC 1, Amaechi v INEC, Rimi INEC (2005) 6 NWLR (pt 920), 56 etc 
within its constitutional propriety support the argument that the concept of judicial activism had been with and gradually developed through the function of the courts in Nigeria, though the level of courts' activism differed in different areas like interpreting the Constitution or statute.

\section{The meaning and legal basis for judicial activism}

Like any catchword judicial activism acquires its real meaning when construed from context this is because definitions of concept are usually products of individual idiosyncrasies and it is often influenced by the individuals' perception or world view, a combination of various definitions gives a description of the concept. ${ }^{30}$ However, it has been observed by a great philosopher, Aristotle ${ }^{31}$ that:

The notion of law ... has defiled any fully satisfactory definition or explanation. Indeed, the problem of definition of word looms large in jurisprudence and traverses the entire terrain of law, thus creating nightmare for lawyers.

It is instructive to note at the outset that judicial activism is not a monolithic concept rather it can represent a distinct jurisprudential ideas worthy of further investigation. ${ }^{32}$ Notwithstanding, scholars have offered diverse definitions of judicial activism. It may be necessary to give the definition of the concept of judicial activism from the two opposing dimensions proffer by scholars: Judicial Activism is that way of exercising judicial power which seeks fundamental recodification of power relation among the dominant institutions of state, manned by members of the ruling classes. ${ }^{33}$ Similarly, judicial activism is viewed as Peter Russell ${ }^{34}$ as meaning: Judicial activism is the judicial vigour in enforcing constitutional limitations on the other branches of government and their readiness to veto those policies on the branches of government on constitutional grounds.

Against the above backdrop it must be noted that judicial activism can only acquire its real meaning when construed from the context and this depends upon the user's theoretical conception of the role of the courts in democracy. More importantly, the effect is that judicial activism is a conception of the courts' role as transcending the mere application of laws rather it support the notion the courts cannot ignore the laws enacted by the legislature, however it can expound, develop and even change it within its function..$^{35}$ The main justification for this

30 See Ibrahim I. et al, Judicial Activism and Intervention in the Doctrine of Political Question in Nigeria: An Analytical Exposition, 1:2, African Journal of Criminology, 1-4, (2011)

31 Aristotle; The Politics, Rackham's Translation Loeb Classical Librans 1932, IV, II

32 See generally; Keenan D. K.,. Supra note 22,

33 Mohammed Aslam Alias Bhure v India AIR (2003) 2 SCC 576

34 Peter H. R., et tal, FEDERALISM AND THE CHARTER: LEADING CONSTITUTIONAL DECISIONS, 19, (Carleton University Press, Ottawa, 1989)

35 Bhagwati P. N., the Role of Judiciary in Democratic Process: Balancing Activism and restraint., 2:3, JHRLR, 7-8, (1992) 
creative role is the necessity for the reconciliation of the rules with the wider objectives of justice ${ }^{36}$ as can be rightly juxtaposed with observation of Oputa JSC thus;

The law will have little relevance if it refuses to address the social issues of the day. Legislators make laws in the abstract but the court deals with the day to day problems of litigants and attempts to use the laws to solve these problems in such way as to produce justice. ${ }^{37}$

Therefore where a definer of judicial activism construed it narrowly, as being restricted to mere application of the preexisting legal rules to the given circumstances he tends to consider even a liberal, purposeful or dynamic interpretation of the law as activism. Where a definer construed it as a wider role for court and expect it to perform the function of providing meaning to various opentextured expressions, insufficiently explicit provisions of the Constitution and giving them new meaning as required by the dynamism of law such as changes in changing contemporary and progressive are bound to consider judicial activism not as an aberration but as a normal judicial function.

Instructively, given the federal structure of Nigerian government ${ }^{38}$ judicial activism may be constitutionally invoked to invalidate legislation, legislative or executive actions which are inconsistent with the Constitution. When the courts wield their power and strike down legislation their action implicates separation of powers issues because the Court's decision challenges policy choices made by the other institutions of government. However, such a judicial act carries with it the potential for awakening the legislature and the executive, including the choice of reversal through constitutional amendment or re-enactment of the invalidated legislation. ${ }^{39}$ This is a beguilingly simple model of the relationship between the legislature, the executive and the judiciary in a representative democracy with responsible government.

Judicial activism adopting liberal or purposeful approach often professes belief in democratic principles of checks and balances ${ }^{40}$ aimed at producing sub-

36 ibid

37 Oputa C., Toward Greater Efficiency in the Dispensation of Justice in Nigeria, in LAW JUSTICE AND STABILITY IN NIGERIA, ESSAY IN HONOUR OF JUSTICE KAYODE ESO, George Y. A. (ed), 37, (JSMB, Ibaddan, 1993)

38 Calabresi, Steven G., A Government of Limited and Enumerated Powers': In Defense of U.S. v. Lopez, (1995), 94 Michigan Univ. L.R. 752.

39 See generally, Ely, John Hart, DEMOCRACY AND DISTRUST: A THEORY OF JUDICIAL REVIEW, (Cambridge: Harvard Univ. Press 1980) see also Kennedy, D. A. CRITIQUE OF ADJUDICATION (Harvard University Press, Cambridge, 1997), Harwood S., JUDICIAL ACTIVISM: A RESTRAINED DEFENSE 167, (Austin \& Winfield Publishers, London, 1996), Christopher, Wolfe, JUDICIAL ACTIVISM, ( $2^{\text {nd }}$ ed. Totowa, NJ: Rowman \& Littfield Publishers, Inc. 1997), Kenneth, M. Holland, (ed), JUDICIAL ACTIVISM IN COMPARATIVE PERSPECTIVE (Palgrave Macmillan, 1991),

40 Segal, Jeffrey A. Separation of Powers Games in the Positive Theory of Congress and 
stantive results that may achieve the intent of the legislature or framer of the statute and Constitution. ${ }^{41}$ Interestingly, the Court's liberally-oriented activism has led conservatives not eschew activist judicial review when it is, at least theoretically, more consistent with the concept of limited government favored by many conservatives. ${ }^{42}$

Interventionist in the form of a Supreme Court exercise of its power may be viewed as a solution to the problem of how best to enforce rule of law, protect fundamental rights and interests in an oligarchy government as practice in Nigerian. Obviously, then, to make a reasonable decision about the legal disputes require not only an empirical assessment of the probable consequences of alternative processes in the concrete setting of a particular country, but also a judgment about the relative weight to assign to the democratic process in comparison with other values. ${ }^{43}$ Notwithstanding, the concept of judicial activism has been subjected to criticism by it opponents on the ground that it allowed court to usurp the power of other institutions of government however, the best answer to such criticism can be found in the word of Hon Justice Michael Kirby, who posited that:

Nostalgic dreams of judges without choices, devoid of creativity, abjuring all 'activism' may be found in fairy stories. But for judges, lawyers and citizens who are obliged to live in the real world, it is necessary to face up to the requirements of judicial choice. Choice about the meaning of a constitutional text, choice about the interpretation of ambiguous legislation, choice about the application, extension, confinement or elaboration of old principles of the common law to new facts, circumstances and times. $^{44}$

In the opinion of the author of this paper judicial activism is closely connected to the dynamic, creative and objective reading of constitutional text by the court. ${ }^{45}$ In other words, a constitutional interpretation which requires continual updating of the Constitution in line with the perceived community and social expectations posits to achieve the object of the Constitution intended to endure for age long; as rightly observed by Lord Wright in the Australian case of James v. Commonwealth of Australia that:

Courts, 91:1, American Political Science Rev, 28, (1997)

41 Canon, Bradley C., Defining the Dimensions of Judicial Activism, 66:6, Judicature, 236, (1983) and Choper, Jesse H., Judicial Review and the National Political Process, (Chicago, IL: Univ. of Chicago Press,1980)

42 Ibid, See Citizen United v Federal Electoral Commission

43 Dahl, Robert, DEMOCRACY AND ITS CRITICS, 192, (New Haven: Yale Univ. Press, 1989) p. 192

44 Hon Justice Michael Kirby, Judicial Activism: Power without Responsibility? No, Appropriate Activism conforming to duty, 30, Melbourne University Law Review, 577-578, (2006)

45 See Ibrahim I. et al, Supra note 29, 1-4

(C) Palacký University Olomouc, Czech Republic, 2015. ISSN 1213-8770 (print), ISSN: 2464-6601 (online). 
It is true that a Constitution must not be construed in any narrow and pedantic sense. The words used are necessarily general, and their full import and true meaning can often only be appreciated when considered, as the years go on, in relation to the vicissitudes of fact which from time to time emerge. It is not that the meaning of the words changes, but the changing circumstances illustrates and illuminates the full import of that meaning. ${ }^{46}$

\section{Judicial-Legislative interaction enforcing constitutional limitations on legislative actions}

This part of the paper begins with a discussion on the judicial, legislative and executive interactive principles of activism that animate the preposition of judicial activism. The part then analysed some judgments to elucidate the realities concerning the concept of judicial activism. The theory of "institutional interaction," as conceptualized in this paper, may be view as a Nigerian perspectives to the debate over the legitimacy of judicial activism in a constitutional and developing democracy. According to this theoretical exposition, the institution of courts and the legislatures participate in government and with inherent level of interaction in the determination of the proper balanced role the Constitution designed for each institution and enforcing or limiting the balance on Constitutional ground on each. ${ }^{47}$

There is strong rationale to view judicial activism as democratically legitimate in that it provides checks and balances as expected under the doctrine of separation of powers. Importantly, this interaction is continuous on the ground that the judiciary does not necessarily have the last word with respect to constitutionally disputed matters and policies in that the legislatures would almost always have the power to re-enact, reverse, modify, ignore or void a judicial decision nullifying legislation. Consequently the cry of judicial supremacy is objectionable in presence legislative supremacy the sustaining judicial activism within the paradigm of separation of power.

The theory of institutional interaction has emerged theoretically out of the Nigerian experience of constitutionalism and is based on Constitution. The theory of institutional interaction it is claimed, has been made possible by virtue of constitutional provisions, the most important of which are the section 1(3) "Supremacy" clause that override any legislation, legislative or executive action that is inconsistent with the Constitution. According to the section 4(8) legisla-

46 [1936] AC 578, at 614, see also, Attorney-General v. Moagi, [1982] 2 (2) BLR 124 at p.184, where Amissah JP quoted with approval Kentridge JA who, in the case had pointed out that a Constitution such as the Constitution of Botswana, embodying fundamental rights, should, as far as its language permits, be given a broad construction.

47 Goodrich and M Valverde (eds) NIETZSCHE AND LEGAL THEORY (Routledge London 2005) 
tive actions are subject of judicial intervention and the Constitution also forbids the legislature from enacting laws to oust the jurisdiction of the courts. This theory of institutional interaction describes a peculiar feature of the Nigerian constitutional arrangement.

\section{A Judicial-Legislative interaction vide interpretation of legislation}

While it is the power of the legislature to enact law, the interpretation of the law and legislative action stemming there from is vested in the judiciary as represented by the courts. ${ }^{48}$ Essentially, aside from the Constitutional power of judicial interpretation there are certain predictive factors that can stimulate interpretation.

It is instructively posited that the words used in legal instruments may sometimes be abstract, or that their meaning indeterminate when applied to various concrete circumstances, or that the application of law requires an intervening act of interpretation, of which the precise nature and significance is largely undefined and contested. ${ }^{49}$ The consequence of such an (apparently obvious) axiom is that while a distinction necessarily exists between the application of law and its creation, it is often claimed that interpretation, in applying words of often indefinite meaning to various situations, may amount to a creative act and consequently a criticism that judges in interpreting law, in fact participate in its creation..$^{50}$ The correct position can be distilled from the observation of Ogwuegbu JSC in DSSS v Abgakoba ${ }^{51}$ that the Constitution of the Federal Republic of Nigeria is written organic instrument. It is a mechanism under which our laws are made and not mere Act of Parliament or a Decree which declares what law is. It has been an accepted canon in interpretation of document to interpolate into the text such provisions not though expressed as are essential to prevent the defeat of their purpose and this applies with special force to the interpretation of Constitution which, since they are designed to cover a great multitude of necessarily unforeseen circumstances, are cast in general language which are not constantly amended. ${ }^{52}$ Though the problem inherent in judicial exercise of interpretative power is stated by MacLean that: ... the process of interpretation is not

48 MacLean 'RESPONSIBILITY AND THE ACT OF INTERPRETATION' IN MACLEAN, MONTEFIORE \& WINCH (EDS) THE POLITICAL RESPONSIBILITY OF INTELLECTUALS, 161, (Cambridge University Press Cambridge 1990)

49 Federal Republic of Nigeria v Osahon (2006) 4 MJSC 1 at 57-58

50 Marmo A ., INTERPRETATION AND LEGAL THEORY, 124, (Clarendon Press Oxford 1994)

51 (1999) 3 SC 59 p 82, see also Nafiu Rabiu v The State pp 300-301, where Udo Udoma JSC said; "whenever it is possible and in response to the demand of justice the courts lean to the broader interpretation unless there is something in the rest of the Constitution to indicate that the narrow interpretation will best carry out the object and purpose of the Constitution. I don't conceive it is the duty of this court to construe any of the provision of the Constitution as to defeat the obvious ends the Constitution was designed to serve."

52 ibid 
a humble one... rather than being the servants of the text, interpreters threaten to become its masters by devising and applying the rules by which sense is made of it; indeed, they threaten to become its masters to the point of laying down the law themselves. ${ }^{53}$

There are rules of legal methodologies for interpretation such as the Literal Rule, the Golden Rule,' the 'Mischief Rule, Ejusdem Generia, Blue Pencil, Severability principle, these are mere semantic aids rather than linguistic devices for reading the text of the Constitution or Statutes. The absence of recognised, single and all encompassing binding methods of interpretation, and the resulting potential for lack of precision is particularly problematic as rightly observed in the case of Awolowo v Shehu Shagari ${ }^{54}$ per Fatai Williams CJN that:

Some of these canons of interpretation take the form of broad principle only; consequently a common feature of most of them is that they are of little practical assistance in settling doubts about interpretation in particular cases. This is partly due to vagueness, but also because in many cases, where one canon appears to support a particular interpretation, there is another canon, often on equal status, which can be invoke in favour of an interpretation, which could lead to a different result.

The above court proposition established the fact that some cannons of interpretation take the form outlined, especially in the cases of constitutional law. These common principles of statutory interpretation have been considered unsuitable for interpretation of constitutional provisions, which in the nature of things tend to lay down general principles. Onu JSC observed that:

It is important to state that the Constitution cannot condescend in its description of every right guaranteed therein. The Constitution is an organic document which must be treated as speaking from time to time, it can only described rights it guarantees in broad terms, it is for the court to fill the fundamental right provisions with content such that would fulfill its purpose and infused them with life. A narrow and literal construction of human right or any provision in our Constitution can only make the Constitution arid in the sphere of rights. Such approach will retard the realization, enjoyment and protection of those citizen's rights and freedom and it is unacceptable. ${ }^{55}$

Thus, there is no principle of interpretation firmly settled than the rule that court must deduce the intention of the legislature or framers of the Constitution from the words used in the law. If the words are in any way ambiguous, it is reasonably capable of more than one meaning of the provision in question the court may depart the natural meaning of the word. This preposition is supported by

53 MacLean, Supra note 47, 161,

54 ibid P 53, (1979) 6-9 SC 51 at 64

55 DSS v Agbakoba p. 95, Salmond, Jurisprudence, pp 131-140

(C) Palacký University Olomouc, Czech Republic, 2015. ISSN 1213-8770 (print), ISSN: 2464-6601 (online). 
the observation of Pat Acholonu JSC in the case of FRN V Osahon ${ }^{56}$ that: Where a statute makes the meaning of a provision difficult to discern properly, it is the indispensible right of the court to explore deeper and try to make sense out of it in the context of the primary law so that it would, on its operation, following the construction of the court have meaning which it eventually wears and which would help to promote law optimized the cause of justice, the advancement of sociological jurisprudence of the rule of law.

It is contended in this paper therefore that words of Constitution or legislation may sometimes have a penumbra of uncertainty occasioning some marginal cases especially from the scenarios above enumerated. Therefore, if marginal cases must occur the duty of a judge in construing them must be legislative. ${ }^{57}$ More importantly the spirit of the constitution or statute is a fact unlikely to be encapsulated in the single word and even the whole text of the laws. It can rather be apprehended through adaptation of the text to diverse circumstances imposed with the passage of time. This is because constitution or statute is meant to endure for ages to come and to meet the various cases of human affairs. In its decision the Supreme Court ${ }^{58}$ citing the case of Nafiu Rabiu v The State ${ }^{59}$ per Udo Udoma JSC said,

...where the question is whether the Constitution has used an expression in a wider or narrow sense the court should always lean where the justice of the case so demands to the broader interpretation unless there is something in the context or in the rest of the Constitution to indicate that the narrow interpretation will best carry out its object and purpose.

Thus, rather than relying on predetermined meaning, the spirit of the laws admits shift of meaning. This is the kind of challenges court is expected to meet. It is also a challenge the contemporary constitutional or statutory text are suited for due to their relatively indeterminate language. Obaseki JSC in Attorney General Bendel State v Attorney General of the Federation said: While language of the Constitution does not change, the changing circumstances of progressive society for which it was designed can yield a new and further import to its meaning. Thus, principles upon which the Constitution is designed rather than the direct operation or literal meaning of the words used should measure the purpose and scope of its provisions. ${ }^{60}$

Juxtapose this preposition with the case of PDP $\mathrm{v}$ INEC where court was faced with the interpretation of the word die in section 37 and 45 of (Constitution and Transition) Decree 1999, to remedy the development which the Decree

56 (2005) 25 NSCQR 512 at 537

57 Hart, H L A, THE CONCEPT OF LAW, 123, (Clarendon Press, 1961, 1994 ed) He first coined the term 'penumbra of doubt' when discussing a rule's scope or coverage:

58 FRN v Osahon ibid

59 Nafiu Rabiu v The State (1981) 2 NCLR 326

60 (1981) 10 SC 179-180

(c) Palacký University Olomouc, Czech Republic, 2015. ISSN 1213-8770 (print), ISSN: 2464-6601 (online). 
failed to provide and which is inevitably placed before the court to determine. The Court in exercising its interpretative power, inferred from the text of the Constitution in line with the development by construing the word die to admit further meanings which may be; stop living, stop working or stop existing within a rule as to death. Thus A judge has no discretion to include resignation, mental incapacity within such a rule. ${ }^{61}$

One significant conclusion that can be drawn from the foregoing preposition on the penumbra nature of the words of Constitution or legislation is to accentuates the need for a judge to pay due regard to legislative intent without limiting the task of interpretation to the ascertainment of that purpose. The following is a very important illustration, closely related to the capacity of judges to intelligently articulate their positions in terms of plausible constitutional interpretation. How, for example, could a rabble in Muslims' Boko Haram, based in the cities of Northern Nigeria, possibly be authorised to call onto the heads of all the Christian and other religious followers in the Country for all future time a blood curse such as would justify their demand for Islamisation of the Country? How, in the context of a religion dedicated to the message of the love of God, and of one another, could such a passage possibly be so interpreted? How, other than by the most mindless literalism, could anyone construe any verse of such meaning, as Muslims Boko Haram did, to justify their demand for Shariah in Nigeria and the dreadful acts of bombing and killing perpetrated against innocent citizens?

It is this paper's belief, a good illustration of the dangers of literalism, originalism or textualism. This is such a debased and discredited approach to the interpretation of language (whether in the Quran, Bible or in a constitution or legislation) that it hardly seems necessary to elaborate why it is so misguided. Yet the literalists and the textualists are now in full flight. They want judges to stick as closely as possible to the text of the statute and even, Mirabelle dictum (expression of wonder), to the original intention of the framers of the Constitution. ${ }^{62}$

\section{B Judicial-Legislative interaction vide legislative action}

In this realm, this paper develops a theoretical model of judicial and legislative interaction a contemplation of the doctrine of checks and balances. It uses this to compare outcomes generated in a system of legislative supremacy to outcomes generated in a system in which judicial activism is provided by a legally principled and constitutional activist judiciary. ${ }^{63}$ The paper then shows that judicial activism, even when exhibited by an activist, or politicized, can promote important constitutional values and improve legislative quality relative. From the

61 (1999) 7 SC (pt ii) 30

62 Hon Justice Michael Kirby, Supra note 43, 584

63 See generally James R. Rogers and Georg Vanberg, Resurrecting Lochner: A Defense of Unprincipled Judicial Activism, 23:2 The Journal of Law, Economics, \& Organization, 443, (2010), 
outset it is instructive to note that judicial activism of the court cannot be used to query the legislative power to enact laws that is not within the prerogative of the judiciary. The Courts are most often reluctant to rule in favour of invalidation of legislation.

However, the Courts as the custodian of the Constitution may have a willing ability to invalidate legislation in the face of its aberration. In support of this preposition it is contended that legislative action must always be based on the Constitution, thus is posited that in any of the following theoretical prepositions where the legislature fails thereon judicial activism is invited on constitutional ground. They are:

1. When legislation offends the principle of separation of power or the principle of federalism;

2. When legislation is inconsistent with the provision of the Constitution;

3. When legislation is aimed at taking away individual rights guaranteed under the Constitution; and

4. When the legislature failed to comply with the procedure set down to doing a particular act.

Within the above framework, it is neither judicial institution trespasses on the role of the legislature. Legislature respects the judicial rule in order to avoid interfering with the role of the courts. The courts respect legislative propriety to make, amend, repeal, re-enact laws and do not become involved with the internal workings of the legislature. Instructively there is absent of protection against judicial intervention on legislative function in the Nigerian Constitution rather it further prevent such intrusions by forbidding the legislature from enacting laws that oust or purport to host the jurisdiction of judicial function. Lord Woolf ${ }^{64}$ was prepared to define a limit on the supremacy of parliament which it would be the responsibility of the courts to identify and uphold. He explicitly said:

As a matter of fundamental principle, it is my opinion that the survival and flourishing of a democracy in which basic rights (of which freedom of expression may be taken as a paradigm) are not only respected but enshrined requires that those who exercise democratic, political power must have limits set to what they may do: limits which they are not allowed to overstep. If this is right, it is a function of democratic power itself that it be not absolute. ${ }^{65}$

A famous example of such intrusion is demonstrated in the case of Oputa v Babangida, ${ }^{66}$ the Supreme Court courageously held that: The power given to

64 Lord Woolf, Droit Public - English Style, Public Law, 57, (1995) culled from, Chief Justice Robert French AC The Courts and the Parliament (2012), Queensland Supreme Court 65 Id Seminar, Brisbane, pp 5-6

66 (2003) 1 SC (pt iii) 86 
Parliament to make laws in regard to tribunal of inquiry as reflected in the legislative Lists contained in the relevant provisions of the schedule to the 1963 constitution was, for whatever reasons, denied the National Assembly in both that 1979 and 1999 Constitutions of the federal Republic of Nigeria. Without such constitutional provisions, no valid law can be made, or can exist, standing on its own and of a general nature, to apply throughout the Federation of Nigeria on the strength of which the President may set up a tribunal or commission of inquiry. This is because there is no constitutional authorizing the passage of such for the Federation of Nigeria by the federal legislature. It is the limits set under relevant provisions of the Constitution that define and determine the frontiers of the laws that can be enacted.

A case which seemed to favour some such intrusion include for instance the Attorney General Ogun State \& Ors v Attorney General of the Federation ${ }^{67}$ the Supreme Court held that in so far as any Act of the National Assembly provides for Joint Local Government Account Allocation Committees for each State to regulate the manner the amount allocated to the States for the benefit of the Local Governments is to be distributed, such Act is inconsistent with Section 162 (8) of the 1999 Constitution. This is what Sections 1 and 2 of the Act seek to do in this case that may have an adverse effect on democratic norms of the country. The basis for the court position in this case is on the principle of federalism which presupposes an autonomous existence for the federal and state within the constitutional framework. Similarly in Attorney General Ondo State v. Attorney General of the Federation \& Others, ${ }^{68}$ the Supreme Court held that the provisions of the Act (ICPC) impugned on the cardinal principles of federalism, namely, the requirement of equality and autonomy of the State Government and non-interference with functions of State Government. This is true, notwithstanding, both the States and Federal government share the power to Legislate in order to abolish corruption and abuse of office. So also is the case of Attorney General Abia State \& Ors v Attorney General of the Federation ${ }^{69}$ this Court held that apart from the power conferred in item II of the Concurrent Legislative List and Section 7 (6) (a) of the 1999 Constitution, (Power to make provision for statutory allocation of public revenue to Local Government Councils in the Federation) the National Assembly does not possess any other power to enact laws affecting local government.

The proposition of legislative-judicial interaction in this perspectives is not peculiar to Nigeria as in the Indian case of Golaknath v Punjab ${ }^{70}$ for instance the Supreme Court ruled that Parliament could not curtail any of the fundamental rights in the Constitution. Although it backtracked on the forcefulness of this decision some six years later, the court continued to assert that in principle no

67 (2002) 18 NWLR (pt 798) 232 or (2002) 12 SCNJ 199 or (2002) 12 SC (pt ii) 1

68 (1983) 2 SCNLR 269

69 (2002) 4 SCNJ or (2002) 4 SC (pt i) 1

70 AIR 1967 SC 1643 
institutional body could alter the democratic essence of the Constitution. This case initiated and developed the court's jurisprudence around what became known as the "basic structure doctrine". In terms of this doctrine, the court was in charge of preventing the erosion of those enduring values that constitute the essence of constitutionalism. ${ }^{71}$

Similarly, in Kesavananda Bharati v State of Kerala ${ }^{72}$ by a majority of 7-6, the court held that under Article 368 of the Constitution, Parliament undoubtedly had power to amend any provision of the Constitution but the amendatory power did not extend to alter the basic structure or framework of the Constitution. The Supreme Court was of the view that the basic structure of the constitution included, inter alia, that Constitution is supreme; the form of government is republican and democratic; the doctrine of secularism; the doctrine of separation of powers between the legislature, the executive and the judiciary, and the nature of federal character of the Constitution. This decision is a typical manifestation of creativity in the form of judicial activism. ${ }^{73}$

Notwithstanding the judicial position in the above cases, it is apposite to state that the legislature is not accountable to the courts in respect of their legislative functions. However, the legislature is accountable for creating an inroad to judicial intervention in determination of the legality and or consistency of such functions. While deciding the above cases, the court kept in mind the difference between legality, consistency and merit as also between judicial propriety and merit of its intervention. It may thus be argued that legislature invited judicial activism for their preferences as democratically elected members of government. There is therefore significant force in the observation of Venderbit that: it is in the courts and not the legislature that our citizens are primarily fallen keen, cutting edge of the law. If they have respect for the work of the courts, their respect for the law will survive the shortcomings of every other branch of government. However if they lose their respect for the work of the courts, their respect for law and order will vanish with it to the detriment of the society. ${ }^{74}$

Instructively therefore, it is more appropriate for courts to intervene against legislative aberration of the constitution at least when reviewing ordinarily their action or legislation. Such judicial activism represents a warranted intrusion of the judiciary into democratic decision making. ${ }^{75}$ This paper thus contends that

71 See Sathe, S. P. JUDICIAL ACTIVISM IN INDIA: TRANSGRESSING BORDERS AND ENFORCING LIMITS, 6 \& 99 (New Dehli, OUP, 2002)

72 (1973) 4 SC 225

73 A Divan, "Judicial activism and democracy", a lead opinion in The Hindu newspaper of 2 April 2007 www.hinduonnet.com/2007/04/02/stories/2007040200941000.htm

74 Venderbit A., THE CHALLENGES OF LAW REFORM (Princeton University Press, Princeton, 2002) cited in Uwais M. L., The Evolution of Constitutionalism in Nigeria: the Role of the Supreme Court under the 1979 and 1999 Constitution (NIALS, Lagos, 2006), p. 8

75 See Peter, A. A.; 'Judicial Review of Nigerian Laws: An Equitable Balance Wheel of the 
judicial activism of the courts' invalidation of legislation is justified and capable of achieving and stimulating the followings:

1. Eliminate imperfections arising from hasty drafting of statutes or absurdities that could only be manifested in concrete situations.

2. Expose the lacuna in a legislation and give direction to assist amendment

3. Suppress the mischief which the law aimed at and advance remedy

4. Serves a purpose of awakening the legislature conscience to make amend

5. Provide generally-applicable rules for future; it is done, so that their orders may resemble legislation to some onlooker.

6. Inspire the legislature to re-enact an invalidated legislation.

Thus where there is constitutional provision setting out the procedure for any legislative action any default in the procedure in exercise of legislative power is actionable and liable to judicial scrutiny ${ }^{76}$. The justification for judicial activism within this premises is that if in the process of exercising legislative power by the National or states' Assembly there is such a constitutional defect as to lead to an interpretation to the effect that a bill was not passed according to law, that is, it does not follow the procedure laid down under the constitution of passing of the bill, then the bill which has passed through such exercise is null and what the President assents to, an exercise of the executive power within the legislative process is a nullity, the Supreme Court in exercise of its jurisdiction under section 212 when there is a dispute under the section could adjudicate on the issue. ${ }^{77}$

Conclusively, the limitations on legislative authority and affirmative action guaranteeing liberty can be preserved in practice no other way than through the medium of the courts of justice whose duty it must be to declare all acts contrary to the manifest tenure of Constitution void without this, all reservations of the particular rights or privileges would amount to nothing. ${ }^{78}$ Thus, the notion of judicial supremacy cannot be real since the courts do not have the last say in view of the legislative power to amend, re-enact or ignore an invalidated legislation as succinctly explained by the Supreme Court that:

Federal System', pp in ISSUES IN JUSTICE ADMINISTRATION IN NIGERIA, Fassy Adetokunbo O. Y (ed.), 66-67, ( VDG International Limited, 2008) pp. 1-19 at p. 18, Uwaifo, S. O., THE COURT - AN INSTRUMENT OF JUSTICE AND DEMOCRACY 152, (MIJ Professional Publishers Limited, Nigeria, 1995), Awotokun, K. 'Governance and Legislative Control in Nigeria: Lessons from the Second and Third Republic', San-Franciso: International Scholars Publications, 4 (1998)

76 Alabi, M.O.A., Quis Custodiet Custoded? Scope and Limit of Legislative Powers, PERSPECTIVES OF THE LEGISLATURE IN THE GOVERNMENT OF NIGERIA, Alabi \& Egbewole (eds.) 284 (African Training Research Centre in Administration for Development (CAFRAD), Morocco, 2010)

77 (1981) 10 SC 179-180

78 Alexander Hamilton, THE FEDERALIST PAPER NO 78, 352-358, (Penn state Electronic Classic Series Publication, 2009) 
The National Assembly has the power, in the course of legislating, or making law, to nullify or abrogate decisions of any court of law, including the Supreme Court, the highest Court of the land. In other words, courts of law cannot question the vires of the legislature to nullify or abrogate an invalidated law and once that is done, the particular decision of the court will no more have the force of law. But that is only one side of the coin. The other side is that the courts, in the exercise of their judicial powers under Section 6 of the constitution, have the jurisdiction to nullify legislation, which is not enacted in accordance with the constitution ${ }^{79}$.

\section{Conclusion}

It is the conclusion of this paper that judicial activism is a noble concept for attaining justice and achieving democratic development and well entrenched in doctrine of separation of powers. Therefore, it is expedient to note that in exercising interpretative role or disputes settlement courts must employ modes of interpretation that are consistent with an activist approach to avoid absurdity or perpetration of injustice which is not intended by the Constitution. These models include the broad, liberal approach and the contextual, purposive approach.

It is only those modes of interpretation that take into account the purposes or objects of the Constitution; the context and the overarching principles on which the Constitution was founded; as well as the values underlying the inclusion of a particular right in the Constitution that are truly consistent with an activist nature of interpreting the Constitution. The Nigerian Constitution provides for separation of power between the three arms of government i.e. the legislature, the executive and the judiciary. Each is no doubt supreme in its area of authority as conferred on it by the Constitution but in so far as it confines itself to and act within the power conferred on it. If it exceeds such powers or acts in contravention of it or in conflict with the provision of the Constitution, it would be the duty of the judiciary to put it in check at the instance of any aggrieved. There is no doubt about the fact that no Court would abdicate its authority in this regard. For example if the resolution of any of the Houses National Assembly relates to matter within its competence, no matter how offensive it might appear to be, the Court would not interfere provided no outside right is infringed. Each arm of government is sworn to protect, preserve and defend the Constitution and the Court would in my view be failing in it duty if it hold itself helpless and unable to offer redress to an aggrieved party whose right is infringed or threatened. ${ }^{80}$

Judiciary is primarily a legal institution that exercises both constitutional and statutory interpretation while establishing precedents intended to direct the decisions of all lower courts. Notwithstanding, the Court is also a political

79 Id

80 Tony Momoh v The Senate (1981) 1NCLR 21

(c) Palacký University Olomouc, Czech Republic, 2015. ISSN 1213-8770 (print), ISSN: 2464-6601 (online). 
institution that is situated in a complex separation of powers ${ }^{81}$ providing checks and balances with justices who are members of the society and hold their own political values and ideology. The judiciary, represented by courts cannot, on its own volition, implement its decisions, as the justices merely have judgment and must rely on the support of the elected branches. The justices' decisions, as a result, often recent multiple considerations is related to the law, politics, and the Court's position in the larger separation of powers. ${ }^{82}$

This paper concludes with the preposition of Hon Justice that: It is to be hoped that....it will emerge the beginnings of a more realistic understanding of the duties and responsibilities of the judiciary, the genius that lies behind its creative capacity, the complete legitimacy of properly fulfilling that capacity and the serious error of formalism, originalism and other non-contextual approaches to the ascertainment of the content of law. Truly, it is those who preach these doctrines who are the activists. They are seeking to change the creative features of our law and the functions of the judicial branch that have existed for centuries. They must not succeed for theirs is a counter-reformation that would put back the course of legal history. ${ }^{83}$

Certainly, the judiciary in Nigeria with its power of finality of decisions on interpretative and adjudicatory jurisdictions cannot be on the same constitutional pedestrian with the executive and legislative organs whose actions, inactions, omissions, decisions or interpretations of the law and the constitution may be call to question before the judiciary. The legislature and executive though enjoy supremacy, the fact is still that their supremacies are still subject to the constitutional supervision by the judiciary to ensure that the will of the people of Nigeria as enshrined in the Constitution is strictly complied with by the organs, and that is the constitutionalism; the overriding judicial activism and oversight of the political branches of government.

81 Re-Olafisoye (2004) 1 SC (pt 1) 27 at 54

82 As Alexander Hamilton Notes in Federalist No. 78.

83 See Justice Michael Kirby, Supra note 47, 592. 